\title{
Transient increase of ATP as a response to temperature up-shift in Escherichia coli
}

\author{
Jaakko Soini ${ }^{1}$, Christina Falschlehner ${ }^{1}$, Christina Mayer ${ }^{1}$, Daniela Böhm¹, \\ Stefan Weinel ${ }^{2}$, Johanna Panula ${ }^{1}$, Antti Vasala ${ }^{1}$ and Peter Neubauer*1,2
}

Address: ${ }^{1}$ Bioprocess Engineering Laboratory and Biocenter Oulu, Department of Process and Environmental Engineering, University of Oulu, P.O.Box 4300, FI - 90014 Oulu, Finland and 2Institute for Biotechnology, Department of Biochemistry/Biotechnology, Martin-Luther-University Halle-Wittenberg, Kurt-Mothes-Str. 3, D-06120 Halle, Germany

Email: Jaakko Soini - jaakko.soini@oulu.fi; Christina Falschlehner - christina.falschlehner@aon.at; Christina Mayer - sinamayer@hotmail.com; Daniela Böhm - daniela.boehm@tu-bs.de; Stefan Weinel - stefan.weinel@gmx.de; Johanna Panula - jopanula@paju.oulu.fi; Antti Vasala - antti.vasala@oulu.fi; Peter Neubauer* - peter.neubauer@oulu.fi

* Corresponding author

Published: 0 I April 2005

Microbial Cell Factories 2005, 4:9 doi:10.1 186/1475-2859-4-9
Received: 04 February 2005

Accepted: 01 April 2005

This article is available from: http://www.microbialcellfactories.com/content/4/I/9

(C) 2005 Soini et al; licensee BioMed Central Ltd.

This is an Open Access article distributed under the terms of the Creative Commons Attribution License (http://creativecommons.org/licenses/by/2.0), which permits unrestricted use, distribution, and reproduction in any medium, provided the original work is properly cited.

\begin{abstract}
Summary
Background: Escherichia coli induces the heat shock response to a temperature up-shift which is connected to the synthesis of a characteristic set of proteins, including ATP dependent chaperones and proteases. Therefore the balance of the nucleotide pool is important for the adaptation and continuous function of the cell. Whereas it has been observed in eukaryotic cells, that the ATP level immediately decreased after the temperature shift, no data are available for $E$. coli about the adenosine nucleotide levels during the narrow time range of minutes after a temperature up-shift.

Results: The current study shows that a temperature up-shift is followed by a very fast significant transient increase of the cellular ATP concentration within the first minutes. This increase is connected to a longer lasting elevation of the cellular respiration and glucose uptake. Also the mRNA level of typical heat shock genes increases within only one minute after the heat-shock.

Conclusion: The presented data prove the very fast response of $E$. coli to a heat-shock and that the initial response includes the increase of the ATP pool which is important to fulfil the need of the cell for new syntheses, as well as for the function of chaperones and proteases.
\end{abstract}

\section{Background}

Bacteria, as all kind of organisms, respond to a sudden increase of the temperature by a heat shock response which induces a specific set of proteins. This stress system belongs to the best-studied cellular responses. As the protein composition of a cell determines substantially the cellular functions, the heat shock response is mainly understood in terms of protein synthesis and composition.
The heat shock response of $E$. coli is mediated by the alternative sigma factor $\sigma^{32}$ ( $r p o H$ gene product) and leads to induction of more than 20 heat shock proteins $[1,2]$. In difference to other stress responses of $E$. coli which in a regulatory cascade first lead to synthesis of the respective sigma factors which then, consecutively, direct the transcription of their genes, the transcriptional induction of the heat shock proteins can start very fast after a heat shock. This first fast synthesis of heat shock proteins is transient, followed by an adaptation period with a lower 
rate of heat shock protein synthesis and later reaches a new steady-state level $[1,3]$. This is because a cell also under non-stress conditions contains a set of a low number of $\sigma^{32}$ molecules (about 10-30 molecules; $[4,5]$ ). Those molecules although possessing a high binding affinity for the RNA polymerase [6], however, are rarely transcriptionally active, because of sequestering by binding to DnaK, which together with its cochaperones DnaJ and GrpE associates with $\sigma^{32}[7,8]$ and mediates its degradation by the FtsH protease [9]. The release of $\sigma^{32}$ from the DnaK chaperone is regulated by the amount of missfolded proteins which may accumulate either when existing proteins lose their structure, or when new-synthesised proteins do not fold properly, which is the characteristic intracellular signal of a heat shock [10] but also may occur under strong overexpression of recombinant proteins [11]. Once released from DnaK, $\sigma^{32}$ binds to RNA polymerase, is stabilised and initiates the synthesis of the heat shock proteins. This mechanism due to the high affinity of $\sigma^{32}$ for binding to RNA polymerase results in the synthesis of heat shock proteins to a concentration of about $5 \%$ of the total cellular protein [1].

The physiological response of $E$. coli towards a heat shock is more complex than just the synthesis of heat shock proteins, including transient growth stop, changes in the cell membranes due to changes in the ratio of lipids and integral membrane proteins [12], and probably also transient DNA relaxation [13]. In higher eukaryotes, one of the most immediate effects of a heat shock is an extensive disruption of the cytoskeleton [14,15]. From the metabolic side already early studies have shown that the maintenance energy requirement increases with increasing growth temperature [16-19] and the yield coefficient $\mathrm{Y}_{\mathrm{X} / \mathrm{S}}$ was observed to decrease, possibly in connection to the higher protein turnover [20]. A number of authors also reported increased respiration rates in relation to the specific growth rate at higher temperatures, e.g. for A. aerogenes (Klebsiella pneumoniae) [21]. (referred by [22])

The group of more than 30 heat shock proteins involves mainly proteases and chaperones, being involved in the degradation of improper folded proteins. The function of these proteins is connected to the hydrolysis of ATP, such as proteolysis by Lon, FtsH and Clp in E. coli [23-25], and the action of the chaperone complexes GroEL/ES and DnaK/J/GrpE [26,27]. Although a number of in vitro studies have been performed revealing this ATP dependence (e.g. [28]), only limited information is available about the response of the in vivo ATP level after a temperature shift. Different authors (e.g. [29-31]) found in higher eukaryotes a fast decrease of the ATP level to less than $50 \%$ after a temperature up-shift parallel to induction of heat shock proteins.
In E. coli the ATP concentration has been mainly followed in steady state conditions. For instance it was reported to increase several fold in correlation with the specific growth rate $[32,33]$. In response to stress ATP or the total adenylate concentration have been followed after cold shock, where both decrease [34], after UV radiation, where the ATP level transiently increased twofold [35], with a following decrease in $r e c A^{+}$cells, which the authors relate to the action of substrate level phosphorylation. Also the levels of ATP and other nucleotides have been followed after induction of recombinant proteins by IPTG [36].

Studies with an appropriate short-time resolution of the ATP response in heat-shocked E. coli cells have not been published, although those data might be valuable to better understand the in vivo function of heat shock induced chaperones and proteases.

\section{Results}

In response to a heat shock $E$. coli strongly induces the production of a number of proteins with protecting and degrading functions, which are ATP dependent. However, most of the data on protease and chaperone function were obtained by in vitro studies, and there are still nearly no data available indicating, that there is a sufficient level of ATP available after a heat shock. Rather confusing results from eukaryotes suggest, that the ATP level and the energy charge after heat shock quickly decrease, which could be seen as contradictory to the optimum conditions for the function of these proteins. Therefore it was the aim of this study to measure the response of the pool of adenosine nucleotides following a temperature up-shift in E. coli.

Aside from the measurement of the adenylate phosphorylation status we wanted to discuss the results in relation to the cellular metabolism and respiratory activity. Therefore the experiments were performed in a bioreactor, which allowed the measurement of oxygen consumption and carbon dioxide formation, as well as a fast sampling of nucleotides and medium samples.

All cultivations were performed with the E. coli K-12 strain W3110, which was a major strain in the evaluation of the E. coli stress responses. As indicated in the materials and methods section the cultivations were carried out on mineral salt medium with glucose as carbon source to avoid complex reactions in view of amino acid availability. The medium used was originally designed for high cell density fermentations, and therefore insures, that all salts are maintained at appropriate concentrations up to the end of the experiment.

The experiments were performed with a temperature shift from $30^{\circ} \mathrm{C}$ to $42^{\circ} \mathrm{C}$. In this range the viability of the cell 
Table I: Cultivation parameters of parameters from batch cultivations of $E$. coli $W 3110$ at $30^{\circ} \mathrm{C}$ and after a temperature shift to $42^{\circ} \mathrm{C}$. The data are average values from two independent fermentations.

\begin{tabular}{lll}
\hline \multicolumn{1}{c}{ Parameter } & before temperature shift & after temperature shift \\
\hline$\mu\left[\mathrm{h}^{-1}\right]$ & 0.38 & 0.71 \\
$\mathrm{q}_{\mathrm{S}}\left[\mathrm{mmol} \mathrm{g}^{-1} \mathrm{~h}^{-1}\right]$ & 5.1 & 17.4 \\
$\mathrm{Y}_{\mathrm{X} / \mathrm{S}}\left[\mathrm{g} \mathrm{mol}^{-1}\right]$ & 75.6 & 41.4 \\
$\mathrm{q}_{\mathrm{A}}\left[\mathrm{mmol} \mathrm{g}^{-1} \mathrm{~h}^{-1}\right]$ & 2.5 & 8.0 \\
$\mathrm{Y}_{\mathrm{A} / \mathrm{s}}\left[\mathrm{mol} \mathrm{mol}^{-1}\right]$ & 0.30 & 0.51 \\
$\mathrm{Y}_{\mathrm{CO} 2 / \mathrm{S}}\left[\mathrm{mol} \mathrm{mol}^{-1}\right]$ & 1.86 & 0.80 \\
$\mathrm{Y}_{\mathrm{O} / \mathrm{S}}\left[\mathrm{mol} \mathrm{mol}^{-1}\right]$ & 1.76 & 0.85 \\
\hline
\end{tabular}

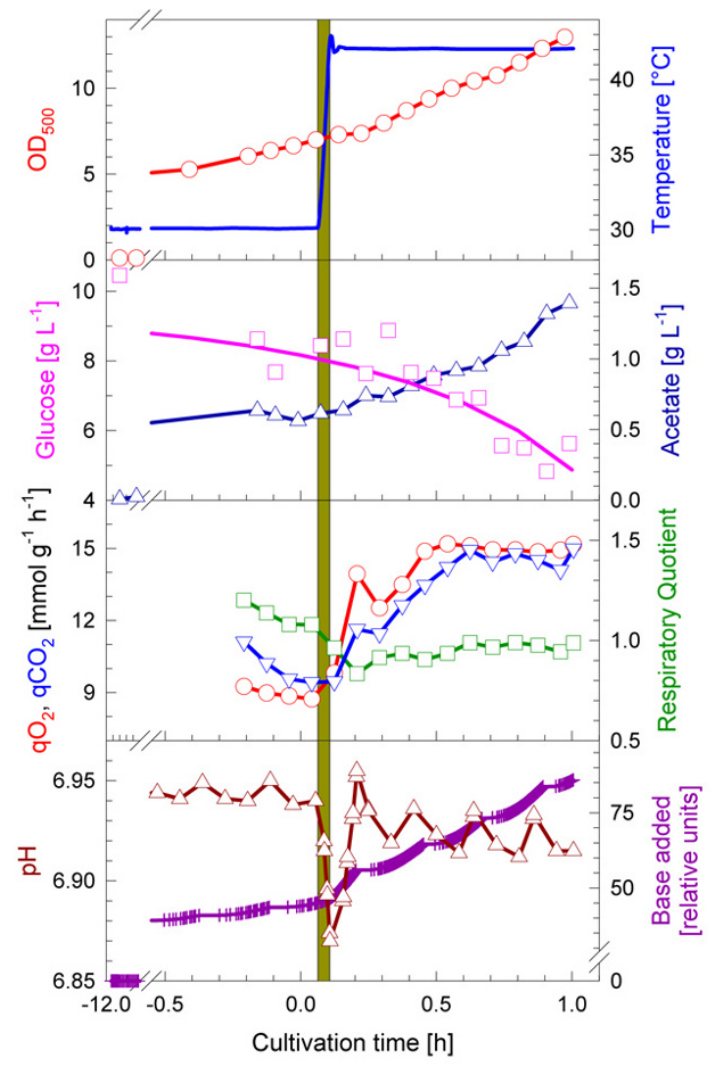

\section{Figure I}

Batch cultivation of $E$. coli W3 I I 0 with a temperature upshift performed at time 0 by switching the temperature setpoint from 30 to $42^{\circ} \mathrm{C}$. (A) $\mathrm{OD}_{500}(\mathrm{O})$, temperature (-); (B) glucose $(\square)$, acetate $(\triangle)$; (C) $\mathrm{q}_{\mathrm{O} 2}(\bigcirc)$, $\mathrm{q}_{\mathrm{co} 2}(\nabla)$, RQ ( $\left.\square\right)$, (D) $\mathrm{pH}(\triangle)$, relative units of ammonia added $(+)$. The grey area indicates the time period of about 5 min during which the temperature increased. is not significantly affected, although the heat shock response is strongly induced. The basic growth behaviour and parameters are shown in Fig. 1 and Table 1, respectively. Cultivations started with a batch phase at $30^{\circ} \mathrm{C}$ for about 11 hours, corresponding to 6 generations, to ensure a steady state of cellular parameters. The specific growth rate $\mu$ was determined to be $0.35 \mathrm{~h}^{-1}$. By following the glucose and acetate concentrations (see Fig. 1) the specific rate for glucose uptake $\left(\mathrm{q}_{\mathrm{s}}\right)$ was determined to be 5.1 mmol g-1 $\mathrm{h}^{-1}$ and the specific acetate production rate $\left(\mathrm{q}_{\mathrm{A}}\right)$ was $2.5 \mathrm{mmol} \mathrm{g}^{-1} \mathrm{~h}^{-1}$. The temperature up-shift to $42^{\circ} \mathrm{C}$ was performed at a cell density of $\mathrm{OD}_{500}=3$ (corresponding to a dry cell weight of $0.675 \mathrm{~g} \mathrm{~L}^{-1}$ ) within $3 \mathrm{~min}$. After the temperature shift the cultivation was continued for one hour. Rapidly after the temperature shift the cells start to increase the specific growth rate to $0.70 \mathrm{~h}^{-1}$ and correspondingly the rates for glucose uptake and acetate production (see Table 1).

During growth at $30^{\circ} \mathrm{C}$ the ATP concentration was detected to be about $1.5 \mu \mathrm{mol}$ per $\mathrm{OD}_{500}$. Concentrations of the other lower phosphorylated adenosine nucleotides were very low during this phase and the resulting adenylate energy charge (EC) was above 0.95. Nucleotide samples were collected in five minute intervals. The ATP concentration increased to $2.75 \mu \mathrm{mol}$ per $\mathrm{OD}_{500}$ immediately after the temperature shift to $42^{\circ} \mathrm{C}$ and also the ADP concentration was found to transiently increase significantly (see Fig. 2). After the transient increase the cellular concentrations of both nucleotides decreased and finally we detected a slight increase of AMP towards the end of the cultivation. Interestingly, the elevation of the ATP level was connected to a total increase of all adenosine phosphates, resulting in a slightly lowered EC to 0.8 (see Fig. 3). However, similar to ATP, also the sum of adenosine phosphates increased only transiently, approaching to the pre-shift level about 20 min after the temperature upshift. The slight increase of AMP to the end of the cultivation influenced the energy charge, which decreased to 0.65 . The transient increase of ATP after the temperature up-shift is connected to a high respiratory activity (Fig. 1C) and occurs in the phase, where also the flux of glucose is rapidly increasing.

In alternate series of experiments the temperature was shifted either from $37^{\circ} \mathrm{C}$ to $48^{\circ} \mathrm{C}$, or from $35^{\circ} \mathrm{C}$ to $55^{\circ} \mathrm{C}$ which leads to growth inhibition and cell death. In both cases the temperature up-shift caused a strong transient increase of respiration and, at least in the first case we also found the rapid increase of ATP, however, the following reduction of the ATP level was much faster (data not shown).

Further it was investigated how the time kinetics of the adenosine nucleotides are related to the expression 


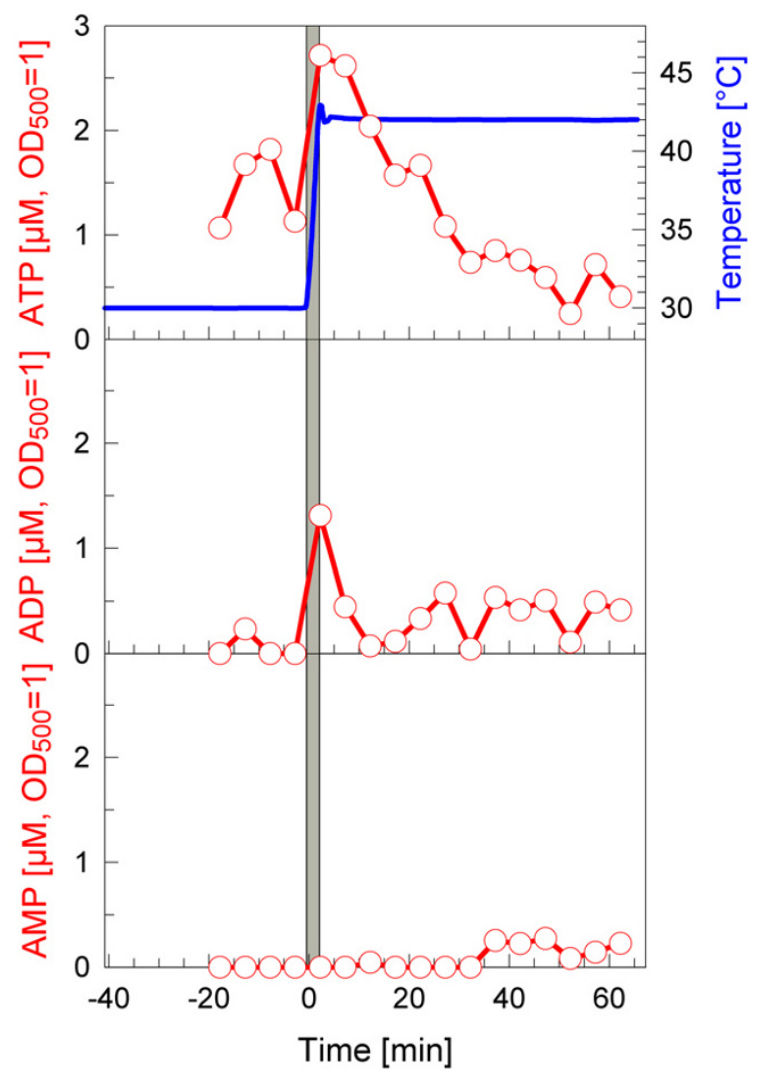

Figure 2

Response of the adenosine nucleotide pool to a temperature up-shift from 30 to $42^{\circ} \mathrm{C}$ in E. coli W3I I0. (A) ATP and cultivation temperature, $(B) A D P,(C) A M P$. The data were obtained during the batch cultivation shown in Figure $\mathrm{I}$.

profiles of typical heat shock genes. These experiments were performed in shake flasks with on-line monitoring of dissolved oxygen and temperature. A fast temperature up-shift was reached by diluting the culture with preheated medium which explains the decrease of $\mathrm{OD}_{580}$ in Fig. 4. Interestingly, the induction of the three investigated heat shock controlled genes was different. The expression of $d n a K$ and $i b p$ were both induced very rapidly and reached their maximum mRNA levels within only 1 min after the heat shock, but lon reached the maximum RNA level after $5 \mathrm{~min}$. A quantitative evaluation of the mRNA amounts showed the highest concentration for $i b p$, but lower expression of $d n a K$ and the lowest for lon. The level of dnaK mRNA was continuously significantly higher expressed than before the shift, but the mRNAs of $i b p$ and lon were very low or not any more detectable after only 10 min. Interestingly, this shut-off of the expression of these

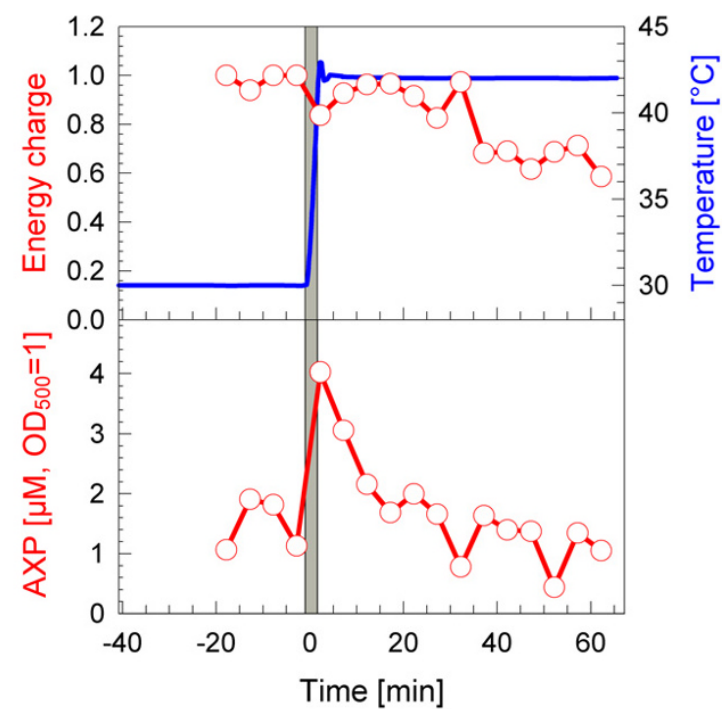

Figure 3

Dynamics of the Energy Charge and sum of adenosine phosphates (AXP) during a cultivation of E. coli W3IIO with temperature up-shift from 30 to $42^{\circ} \mathrm{C}$. Data were calculated from primary concentrations of the adenosine nucleotides shown in Figure 2.

genes is at about the same time when the pre-shift level of nucleotides was re-established.

\section{Discussion}

Our studies indicate, that $E$. coli responds to a temperature up-shift by rapidly increasing respiration and glucose uptake. The increase of glucose uptake is possibly mainly directed to glycolysis and, consequently, to energy production. Concomitantly we detected a significant drop in the $\mathrm{pH}$ and an increase of the acetate level. The higher production of acetate per glucose $\left(\mathrm{Y}_{\mathrm{A} / \mathrm{S}}\right)$ might point to an increase of glycolytic activity, and suggests that the flow to the tricarboxylic acid cycle was not increased correspondingly.

We detected a significant increase of the concentration of the sum of adenosine nucleotides (AXP) directly during the temperature up-shift which possibly is caused by RNA degradation as is concluded from the total RNA concentrations per cell which decreased to less than $50 \%$ if the samples before and after the temperature up-shift are compared (data not shown). This increase of the AXP concentration was connected to a decrease in the energy charge, as the increase of ADP was higher than the increase of ATP. It remains to be investigated whether this relative transient increase of ADP has physiological effects. For example it might be hypothesized that the 


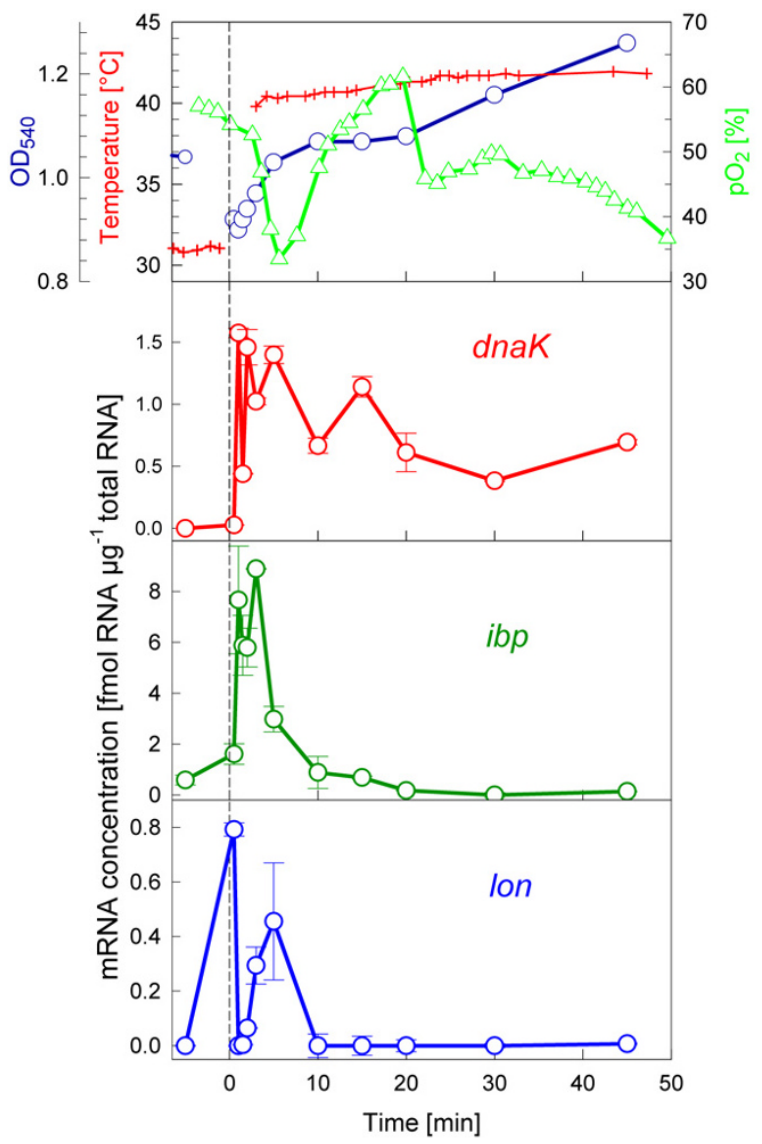

Figure 4

Response of mRNAs in a stirred-flask cultivation of $E$. coli W3 I 10 with a temperature shock from $30^{\circ} \mathrm{C}$ to $42^{\circ} \mathrm{C}$. For experimental details see Materials and Methods.

high concentration of ADP transiently inactivates various chaperones (see e.g. $[37,38]$ ) which bind ADP with higher affinity compared to ATP.

After the heat shock the cells strongly increase respiration and $\mathrm{CO}_{2}$ production which should be related to ain increased glycolytic flux, as correspondingly acetate formation is increased. A similar behaviour of increased glycolytic flux we have observed from other cultivations where a stress was caused by strong induction of a recombinant protein and also provoked a transient increase of the ATP level and higher respiration. However, differently from the investigated temperature up-shift, after induction of the recombinant protein the cells lost their viability [39]. Also a lethal heat shock caused by a temperature up-shift from $37^{\circ} \mathrm{C}$ to $52^{\circ} \mathrm{C}$ [40] or from $37^{\circ} \mathrm{C}$ to $48^{\circ} \mathrm{C}$ (own results, not shown) resulted in a transient increase of ATP, but this was much slower and the increase was only about $30 \%$ with a maximum at about 30 min after the temperature shift.

Our data suggest that similarly as known for the heat shock response, that the response of the nucleotides is transient and the energy charge is restored 15 to $20 \mathrm{~min}$ after the heat shock. After this transient induction of the heat shock response cell growth recovers and it may be hypothesised that the cellular synthetic activities and metabolite pools reach a new steady state.

\section{Conclusion}

This study shows that the heat shock response in E. coli in connection to the adenosine phosphates is different from the response of eukaryotes. Whereas different authors described in eukaryotes an immediate decrease of the ATP level following a temperature up-shift (e.g. [29-31]), in E. coli we found a transient increase, before the ATP level is lowered. It may be hypothesised, but has to be verified by further experiments that this transient increase of the ATP concentration is important for the action of chaperones and proteases and consequently for the function of the cellular system towards a heat shock response.

\section{Methods \\ Strains}

All experiments were performed with the Escherichia coli K-12 strain W3110 [F-, IN (rrnD rrnE) $\left.1, \lambda^{-}\right]$which was kindly obtained by the E. coli Stock Center (New Haven, USA).

\section{Cultivation medium and cultivation conditions}

Phosphate buffered mineral salt medium according to Teich et al. [41] with $10 \mathrm{~g} \mathrm{~L}^{-1}$ glucose and thiamine hydrochloride $\left(0.1 \mathrm{~g} \mathrm{~L}^{-1}\right)$ was used in all cultivations. The $\mathrm{pH}$ of the medium was set to 7.0 before sterilisation by addition of $\mathrm{NaOH}$. For fermentation experiments two precultivations were carried out at the appropriate temperature of the main cultivation. The first culture was performed in 10 mL of nutrient broth (NBII: $1 \%$ tryptone, $0.6 \%$ yeast extract), whereas the second preculture contained $200 \mathrm{ml}$ of the fermentation medium in a $1000 \mathrm{~mL}$ baffled Erlenmeyer flask. Each preculture was used at the exponential growth phase as inoculum for the next cultivation.

The fermentations were performed in a 6 L Biostat ED bioreactor (B. Braun Biotech International, Germany) with a starting volume of $4 \mathrm{~L}$ of mineral salt medium $\mathrm{pH} 7.0$ ). The $\mathrm{pH}$ was controlled to drop not below 7.0 by addition of $25 \%$ ammonia. Air flow (0.002 to $2 \mathrm{vvm}$ ) and stirrer speed (200 to $800 \mathrm{rpm}$ ) were increased stepwise to keep the dissolved oxygen tension above $20 \%$. After the initial batch phase to an optical cell density $\left(\mathrm{OD}_{500}\right)$ of 3 the 
temperature up-shift was performed with a temperature increase from 30 to $42^{\circ} \mathrm{C}$ within $6 \mathrm{~min}$.

Batch cultivations with on-line monitoring of temperature and oxygen were performed in $1000 \mathrm{~mL}$ baffled Erlenmeyer flasks with three side necks for the sensors and a needle for sampling into a syringe. The cultures were performed in $200 \mathrm{~mL} \mathrm{M9}$ mineral salt medium with $10 \mathrm{~g}$ $\mathrm{L}^{-1}$ glucose, $2 \mathrm{~mL} \mathrm{~L}^{-1}$ of trace element solution and $0.1 \mathrm{~g} \mathrm{~L}^{-}$ ${ }^{1}$ thiamine hydrochloride on a magnetic stirrer bar at 1000 $\mathrm{rpm}$ in a tempered water bath. The heat shock was performed by addition of $66 \mathrm{~mL}$ fresh $\mathrm{M} 9$ medium which was preincubated at $100^{\circ} \mathrm{C}$ and following replacement of the flask into another water bath $\left(42^{\circ} \mathrm{C}\right)$. Temperature and oxygen were monitored by sensors (Pt1000, polarographic oxygen electrode from Meredos $\mathrm{GmbH}$ ), connected to the wireless Senbit system (teleBITcom $\mathrm{GmbH}$ ) with on-line data collection.

\section{Analytical methods \\ Cellular growth}

Growth of the cultures was followed by measuring the optical density at $500 \mathrm{~nm}\left(\mathrm{OD}_{500}\right.$, for cultivation in the bioreactor) or $540 \mathrm{~nm}\left(\mathrm{OD}_{540}\right.$, for shake flasks), and by determination of the cell dry weight (CDW). Therefore 1.5 $\mathrm{mL}$ cell suspensions were centrifuged in pre-weighed $2 \mathrm{~mL}$ eppendorf tubes and washed once with $0.9 \%(\mathrm{w} / \mathrm{v}) \mathrm{NaCl}$ solution. After removal of the supernatant the samples were dried to constancy at $60^{\circ} \mathrm{C}$ for at least $24 \mathrm{~h}$. Colony forming units were analysed by plating at least three dilutions and each of these at triple of the culture broth on nutrient bullion plates, which were incubated for one to three days at $37^{\circ} \mathrm{C}$.

\section{Glucose and acetate}

Samples from the cultivation were collected by direct filtration from the reactor through a $0.2 \mu \mathrm{m}$ disk filter. Afterwards the samples were stored at $-20^{\circ} \mathrm{C}$ for further analysis. The analysis of glucose was performed with the hexokinase/glucose-6-phosphate-dehydrogenase method (Kit no. 139106, Roche Diagnostics GmbH, Germany) scaled down to 96-well plates with four parallels for each sample as described by Larsson and Törnkvist [42]. Acetate was analysed with the Kit no. 148261 (Roche Diagnostics GmbH, Germany) correspondingly.

\section{Outgas analysis}

The outgas oxygen and carbon dioxide concentrations were measured with an URAS10E (Hartmann \& Braun $\mathrm{GmbH}$, Frankfurt, Germany). The specific rates $\left(\mathrm{q}_{\mathrm{O} 2}\right.$, $\mathrm{q}_{\mathrm{CO} 2}$ ) were calculated continuously over the fermentation by including fitted biomass values.
Table 2: Probes used in Sandwich hybridization Capture probes were biotin labelled and detection probes contained a Dig tail.

\begin{tabular}{lll}
\hline Name & Sequence (5'-3') & Position \\
\hline dnaK & & \\
Helper probe I & GTCGGGATAGTGGTGTTTTT & 1259c \\
Capture probe & AGAACACCTGGCTGTGCTTG & 1279c \\
Helper probe 2 & CTGGTTGTCTTCAGCGGTAG & 1299c \\
$\begin{array}{l}\text { Detection probe } \\
\text { lbp }\end{array}$ & TTGTCGCCTGCTTCTTCAAC & 1667c \\
Capture probe & ACCAGCCACAGCGATAGCAA & 165c (ibpA) \\
$\begin{array}{l}\text { Detection probe } \\
\text { Helper probe }\end{array}$ & ATCCAGTTCGCTCTCAGCAA & $186 \mathrm{c}(\mathrm{ibpA})$ \\
Lon & ACCACAGCAGATTATCCTG & $215 \mathrm{c}(\mathrm{ibpA})$ \\
$\begin{array}{l}\text { Capture probe } \\
\text { Detection probe }\end{array}$ & ACTCCAGATACTCCGCCTTC & $355 \mathrm{c}$ \\
\hline & GCTGAATGGACTCCTGCAT & $1919 \mathrm{c}$ \\
\hline
\end{tabular}

Analysis of adenosine nucleotides

The adenosine nucleotides were analyzed with an RPHPLC method as described earlier in detail Meyer et al. [43].

\section{Analysis of mRNAs}

$10 \mathrm{~mL}$ samples of cell broth were immediately chilled with $1350 \mu \mathrm{L}$ cold ethanol/phenol (95:5, v/v, pre-cooled at $\left.-20^{\circ} \mathrm{C}\right)$. After centrifugation at $10000 \mathrm{rpm}\left(4^{\circ} \mathrm{C}, 5\right.$ $\min )$ the supernatant was carefully removed, the pellet was resuspended in $1 \mathrm{~mL}$ of RNA Later (Ambion) and the samples were stored in $250 \mu \mathrm{L}$ fractions at $-70^{\circ} \mathrm{C}$ until analysis.

Total RNA extraction was performed with a total RNA isolation kit (A\&A Biotechnology, Gdynia, Poland) according to the instructions of the manufacturer. Total RNA was quantified with the RiboGreen Quantification kit (Molecular probes). Quantitative analysis of $d n a K, i b p$ and $l o n$ mRNAs was performed with a sandwich system earlier described in detail by Rautio et al. [44]. Therefore probes shown in Table 2 were designed using the CloneManager5 program with following submission of the sequences a NCBI BLAST search http://www.ncbi.nlm.nih.gov/BLAST/ to exclude alignments with other $E$. coli genes.

HPLC-purified unlabelled and biotin-labelled oligonucleotide capture probes were purchased from Metabion GmbH (Martinsried, Germany). Dig-tail labelling of the detection probes was performed according to manufacturer's instructions using the Roche Dig-tailing kit $\left(2^{\text {nd }}\right.$ generation, Roche Diagnostics $\mathrm{GmbH}$, Mannheim, Germany).

In vitro RNA standards were designed for the quantitative analysis of each gene. Therefore primers as indicated in Table 3 were used for in vitro transcription (purchased 
Table 3: Primers for synthesis of in vitro RNA standards. The T7 promoter sequence was added to the 5 ' side of all primer I sequences.

\begin{tabular}{lll}
\hline Name & Sequence (5'-3') & Position \\
\hline $\begin{array}{l}\text { dnaK } \\
\text { Primer I }\end{array}$ & CTCTTGTGTAGCGATTATGG & 39 \\
Primer 2 & GTTGTTTGCAGAAGCATCAG & $1860 \mathrm{c}$ \\
Ibp & & \\
Primer I & CCGCTTTACCGTTCTGCTA & 22 (ibpA) \\
Primer 2 & CTATTTAACGCGGGACGTTC & $425 \mathrm{c}(\mathrm{ibpB})$ \\
Lon & & \\
Primer I & ATGAATCCTGAGCGTTCTGA & 1 \\
Primer 2 & CACAACCTGCATACCAGAC & $2342 \mathrm{c}$ \\
T7 promoter & CTAATACGACTCACTATAGGGAGA &
\end{tabular}

from Sigma-Genosys, Cambridge, UK). Left primers (Primers 1) contained the 25 nucleotide T7 promoter sequence at the 5 ' side. Target genes were amplified by PCR from total DNA extracts of E. coli. The PCR products were purified using QIAquick PCR purification Kit and then used as templates for in vitro transcription using the MAXIscript T7 transcription kit from Ambion (Austin Texas, U.S.A.). The in vitro standards were quantified by the RiboGreen RNA Quantification Kit (Molecular probes) and a standard calibration curve with the respective standard was performed at the same plate where the samples were analysed.

Streptavidin MagneSphere Paramagnetic Particles (1 mg $\mathrm{mL}^{-1}$ magnetic particles in PBS, $1 \mathrm{mg} \mathrm{mL}^{-1} \mathrm{BSA}$ and $0.02 \%$ NaAzide) from Promega (Madison, USA) were used as magnetic beads for immobilisation of the target. Sandwich hybridisation was performed in 96-well plates at $50^{\circ} \mathrm{C}$ for $30 \mathrm{~min}$ with constant shaking (700 rpm). Therefore hybridisation solution with a final concentration of $5 \times$ SSC, $20 \%$ formamide, $2 \%$ Denhardt reagent, $3 \%$ dextran sulphate and $0.2 \%$ SDS was added to a final volume of $100 \mu \mathrm{L}$ to each sample. Each well of the plate contained 1 pmol of DIG-tail labelled detection probe, 5 pmol of biotin-labelled capture probe and appropriate dilutions of in vitro transcripts for the standard curve or of the RNA extracts from cultivation samples.

Immobilisation of RNA molecules was done by adding 20 $\mu$ streptavidin coated magnetic beads to each well after hybridisation. DIG labelled probes were bound to AntiDIG-alkaline phosphatase (added 1:2000 in TBS-buffer) and the enzymatic reaction was carried out with AttoPhos (Promega) as substrate. Fluorescence was measured with the Wallac 2 fluorescence reader (Perkin Elmer Life Sciences) at $25^{\circ} \mathrm{C}$ using the Attophos1-program.

\section{Authors' contributions}

SW and PN carried out the fermentations and nucleotide analyses. JS, CF, CM and DB developed the method for analysing the mRNAs and performed the corresponding analysis. JP and AV were included in the wireless analysis with the Senbit system. JS, PN and AV drafted the manuscript. All authors read and approved the final manuscript.

\section{Acknowledgements}

The study was partly supported by the EU project no. QLK3-CT-199900533 "Electric DNA chips for bioprocess control" and the TEKES Neobio program (CORF project).

\section{References}

I. Arsene $F$, Tomoyasu T, Bukau B: The heat shock response of Escherichia coli. Int J Food Microbiol 2000, 55:3-9.

2. Gross CA: Function and regulation of the heat shock proteins. In Escherichia coli and Salmonella typhimurium Cellular and Molecular Biology Edited by: Neidhardt FC, Curtiss III R, Ingraham JL, Lin ECC, Low KB, Magasanik B. Washington, D.C.: American Society of Microbiology; 1996:1382-1399.

3. Bukau B: Regulation of the Escherichia coli heat-shock response. Mol Microbiol 1993, 9:67I-680.

4. Craig EA, Gross CA: Is hsp70 the cellular thermometer? Trends Biochem Sci 1991, 16:135- I40.

5. Ishihama A: Functional modulation of Escherichia coli RNA polymerase. Annu Rev Microbiol 2000, 54:499-518.

6. Arsene F, Tomoyasu T, Mogk A, Schirra C, Schulze-Specking A, Bukau $B$ : Role of region $C$ in regulation of the heat shock gene-specific sigma factor of Escherichia coli, sigma32.J Bacteriol I999, I 81:3552-3561.

7. Gamer J, Bujard H, Bukau B: Physical interaction between heat shock proteins DnaK, DnaJ, and GrpE and the bacterial heat shock transcription factor sigma 32. Cell 1992, 69:833-842.

8. Gamer J, Multhaup G, Tomoyasu T, McCarty JS, Rudiger S, Schonfeld $\mathrm{H}$, et al.: A cycle of binding and release of the DnaK, DnaJ and GrpE chaperones regulates activity of the Escherichia coli heat shock transcription factor sigma32. EMBO J 1996, I5:607-617.

9. Tomoyasu T, Gamer J, Bukau B, Kanemori M, Mori H, Rutman AJ, et al.: Escherichia coli FtsH is a membrane-bound, ATP. dependent protease which degrades the heat-shock transcription factor sigma 32. EMBO J 1995, 14:255I-2560.

10. Tomoyasu T, Ogura T, Tatsuta T, Bukau B: Levels of DnaK and DnaJ provide tight control of heat shock gene expression and protein repair in Escherichia coli. Mol Microbiol 1998, 30:567-58I.

II. Hoffmann F, Rinas U: Roles of heat-shock chaperones in the production of recombinant proteins in Escherichia coli. Adv Biochem Eng Biotechnol 2004, 89:143-161.

12. Mejia R, Gomez-Eichelmann MC, Fernandez MS: Fatty acid profile of Escherichia coli during the heat-shock response. Biochem Mol Biol Int 1999, 47:835-844.

13. Lopez-Garcia P, Forterre P: DNA topology and the thermal stress response, a tale from mesophiles and hyperthermophiles. Bioessays 2000, 22:738-746.

14. Welch WJ, Suhan JP: Morphological study of the mammalian stress response: characterization of changes in cytoplasmic organelles, cytoskeleton, and nucleoli, and appearance of intranuclear actin filaments in rat fibroblasts after heatshock treatment. J Cell Biol I985, I I I: I | 98-12II.

15. van Bergen en Henegouwen PM, Jordi WJ, van Dongen G, Ramaekers FC, Amesz H, Linnemans WA: Studies on a possible relationship between alterations in the cytoskeleton and induction of heat shock protein synthesis in mammalian cells. Int J Hyperthermia 1985, I:69-83.

16. Esener AA, Roels JA, Kossen NWF: The influence of temperature on the energetics of Klebsiella pneumoniae. Biotechnol Bioeng 1983, 25:2093-2098. 
17. Harder W, Veldkamp H: A continuous culture study of an obligately psychrophilic Pseudomonas species. Arch Microbiol 1967, 59:123-130.

18. Pennock J, Tempest DW: Metabolic and energetic aspects of the growth of Bacillus stearothermophilus in glucose-limited and glucose-sufficient chemostat culture. Arch Microbiol 1988, I 50:452-459.

19. Topiwala H, Sinclair CG: Temperature relationship in continuous culture. Biotechnol Bioeng 1971, 13:795-8I3.

20. Dawes EA, Ribbons DW: Some aspects of the endogenous metabolism of bacteria. Bacteriol Rev 1964, 28: I26-149.

21. Senez JC: Some considerations on the energetics of bacterial growth. Bacterial Rev 2005, 26:95-107.

22. Heitzer A: Kinetic and physiological aspects of bacterial growth at superoptimum temperatures. Diss. ETH no. 92/7, Zürich, Switzerland 1990

23. Porankiewicz J, Wang J, Clarke AK: New insights into the ATPdependent Clp protease: Escherichia coli and beyond. Mol Microbiol 1999, 32:449-458.

24. Schumann W: FtsH - a single-chain charonin? FEMS Microbiol Rev 1999, 23:1-II.

25. Suzuki CK, Rep M, van Dijl JM, Suda K, Grivell LA, Schatz G: ATPdependent proteases that also chaperone protein biogenesis. Trends Biochem Sci 1997, 22: I 18-123.

26. Horwich AL, Weber-Ban EU, Finley D: Chaperone rings in protein folding and degradation. Proc Natl Acad Sci U S A 1999, 96: I 1033-11040.

27. Braig K: Chaperonins. Curr Opin Struct Biol 1998, 8:159-165.

28. Sparrer H, Lilie H, Buchner J: Dynamics of the GroEL-protein complex: effects of nucleotides and folding mutants. J Mol Biol 1996, 258:74-87.

29. Lilly MB, Ng TC, Evanochko WT, Katholi CR, Kumar NG, Elgavish $\mathrm{GA}$, et al.: Loss of high-energy phosphate following hyperthermia demonstrated by in vivo 3IP-nuclear magnetic resonance spectroscopy. Cancer Res 1984, 44:633-638.

30. Findly RC, Gillies RJ, Shulman RG: In vivo phosphorus-3 I nuclear magnetic resonance reveals lowered ATP during heat shock of Tetrahymena. Science 1983, 219:1223-1225.

31. Jones KA, Findly RC: Induction of heat shock proteins by canavanine in Tetrahymena. No change in ATP levels measured in vivo by NMR. J Biol Chem 1986, 26 1:8703-8707.

32. Gaal T, Bartlett MS, Ross W, Turnbough CL Jr, Gourse RL: Transcription regulation by initiating NTP concentration: rRNA synthesis in bacteria [see comments]. Science 1997, 278:2092-2097.

33. Petersen C, Moller LB: Invariance of the nucleoside triphosphate pools of Escherichia coli with growth rate. J Biol Chem 2000, 275:393I-3935.

34. Rhodes MW, Anderson IC, Kator HI: In situ development of sublethal stress in Escherichia coli: effects on enumeration. Appl Environ Microbiol I983, 45: 1870-1876.

35. Barbe J, Villaverde A, Guerrero R: Evolution of cellular ATP concentration after UV-mediated induction of SOS system in Escherichia coli. Biochem Biophys Res Commun 1983, I I7:556-56I.

36. Lin HY, Hanschke R, Nicklisch S, Nietsche T, Jarchow R, Schwahn C, et al.: Cellular responses to strong overexpression of recombinant genes in Escherichia coli DNA relaxation and cell death after induction of $\alpha$-glucosidase. In Recombinant Protein Production with prokaryotic and eukaryotic cells. A comparative view on host physiology Edited by: Merten O-W, Mattanovich D, LANG C, Larsson G, Neubauer P, Porro D. Dortrecht, The Netherlands: Kluwer Academic Publisher; 200I:55-74.

37. Mayer MP, Bukau B: Hsp70 chaperones: Cellular functions and molecular mechanism. Cell Mol Life Sci 2005, 62:670-684.

38. Zolkiewski M, Kessel M, Ginsburg A, Maurizi MR: Nucleotidedependent oligomerization of ClpB from Escherichia coli. Protein Sci 1999, 8: 1899-1903.

39. Neubauer P, Lin HY, Mathiszik B: Metabolic load of recombinant protein production: inhibition of cellular capacities for glucose uptake and respiration after induction of a heterologous gene in Escherichia coli. Biotechnol Bioeng 2003, 83:53-64.

40. Tkachenko AG, Pshenichnov MR, Salakhetdinova OI, Nesterova LI: [Role of putrescine and potassium transport in regulating the topological state of DNA during adaptation of Escherichia coli to temperature stress]. Mikrobiologiia 1998, 67:601-606.
4I. Teich A, Lin HY, Andersson L, Meyer S, Neubauer P: Amplification of ColEI related plasmids in recombinant cultures of Escherichia coli after IPTG induction. J Biotechnol 1998, 64:197-210.

42. Larsson G, Törnkvist M: Rapid sampling, cell inactivation and evaluation of low extracellular glucose concentrations during fed-batch cultivation. J Biotechnol 1996, 49:69-82.

43. Meyer S, Noisommit-Rizzi N, Reuss M, Neubauer P: Optimized analysis of intracellular adenosine and guanosine phosphates in Escherichia coli. Anal Biochem 1999, 27 1:43-52.

44. Rautio J, Barken KB, Lahdenpera J, Breitenstein A, Molin S, Neubauer $P$ : Sandwich hybridisation assay for quantitative detection of yeast RNAs in crude cell lysates. Microb Cell Fact 2003, 2:4.
Publish with Bio Med Central and every scientist can read your work free of charge

"BioMed Central will be the most significant development for disseminating the results of biomedical research in our lifetime. "

Sir Paul Nurse, Cancer Research UK

Your research papers will be:

- available free of charge to the entire biomedical community

- peer reviewed and published immediately upon acceptance

- cited in PubMed and archived on PubMed Central

- yours - you keep the copyright

Submit your manuscript here:

http://www.biomedcentral.com/info/publishing_adv.asp 